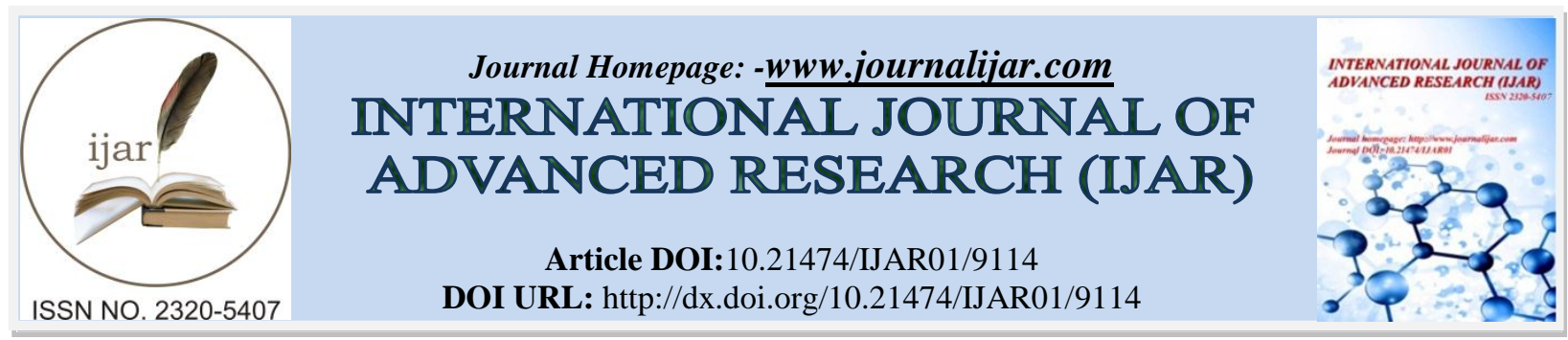

RESEARCH ARTICLE

\title{
IMPACT OF SINGLE SUPER PHOSPHATE FERTILIZER ON BIOCHEMICAL ASPECTS OF FISH (Channa striatus).
}

T.Madhulatha and M. Rajyasree1.

Department of Zoology, Dravidian University (off campus), Kuppam - 517 425, A.P. 1Department of Zoology, Vivek Vardhini College of Arts Commerce,Science and Post Graduate Studies, Jambagh, Hyderabad - 500 095. T.S.

\section{Manuscript Info}

Manuscript History

Received: 22 March 2019

Final Accepted: 24 April 2019

Published: May 2019

\section{Abstract}

Impact of single super phosphate (SSP) on Body weight, Total protein, Amino acids content was studied in Channa striatus by exposing to $400 \mathrm{mg} / \mathrm{l}$ ofsingle super phosphate dissolved in water for 7 and 15 days. SSP showed differential effect on all parameters analysed. SSP caused signifcant decrease in total body weight and total protein content, but an increase in Amino acid levels in liver, muscle and gill tissue. The study indicates SSP has negative impact on protein metabolism of fish..

Copy Right, IJAR, 2019,. All rights reserved.

\section{Introduction:-}

Increased use of pesticides and fertilizers cause not only health hazards to man and animal, but also exert pressure on the eco-balance drawing global attention. Application of chemicals in public health activities and waste treatment are the prime agents of environmental contamination that affect the ecological balance. Use of large scale fertilizers causes severe imbalance in the natural ecosystems. The aquatic organisms are more affected than the terrestrial life (Edwards, 1973) they get bathed continuously in the medium containing the toxicant. The uptake of these chemicals by fish can occur through three major routes namely, gill, body surface and alimentary canal. For centuries fish farmers increased fish yields by fertilizing their fish ponds using Inorganic fertilizer (Bwala and Omergie 2009) Chemical fertilizers enhance the growth of phytoplankton and zooplankton (Saha etal, 1978). Fertilization of pond with organic and inorganic fertilizers is the cheapest and simplest means of increasing aquatic productivity.Fertilizers used in ponds stimulate the growth of microscopic plants called algae. Algae are eaten by microscopic animals (zooplankton) and insects which serve as food for fish. Single super Phosphate (SSP) (16-20\% $\mathrm{P}) \mathrm{Kg} / \mathrm{ha} / \mathrm{yr}$ is used in fish culture. The greatest advantage of Super phosphate as a fertilizer is that the phosphoric acid is fully water soluble, but when Super phosphate is applied to the soil, it is converted into soluble phosphate. Occurrence of nitrogen and inorganic phosphate pollution in aquatic system is due to the indiscriminate usage of fertilizers. These fertilizers induce biochemical, physiological changes in aquatic animals. In view of the reports regarding the impact of fertilizers on bio systems the author felt it desirable to enunciate the effect of single super phosphate on some biochemical aspects of fish.

\section{Material and Methods:-}

Channa striatus It is commonly called as snake head fish. Body is elongated, anteriorly cylindrical and posteriorly impressed and covered with cyloid scales. It may grow to the length of $45 \mathrm{~cm}$. Head to the length of $45 \mathrm{~cm}$. Head depressed and covered with large cycloid scales. Dorsal and anal fins are single, long and without spines. Gill opening is wide and lateral in position. Accessory breathing organs are present.it has been selected for present investigation. Fertilizer selected for the present investigation is commercial single super phosphate obtained from 
local fertilizers shop in Hyderabad.and the concentration of fertilizer used is $400 \mathrm{mg} / \mathrm{l}$ fish were divided into two groups control and experimental. Experimental animals were exposed to SSP for 7 and 15 days. The experiment was conducted in glass aquaria $(40 \times 70 \times 60 \mathrm{~cm})$. The fish were acclimated to the test conditions for 48 hrs before each treatment and they were fed with fish pellets at a ration of $2 \%$ of the biomass twice daily.The water in the aquaria was replaced daily and aerated continuously during the acclimation period. Feeding was stopped $48 \mathrm{~h}$ prior to the experiment and no food was given during the test.

\section{Body Weight:}

Freshwater fish Channa Striatus (stock size) were taken and they were weighed. Their weights were recorded as follows:

Fish weight: (Beaker containing known volume of water + fish) $-($ Beaker containing known volume of water without fish).

Then they were exposed to $400 \mathrm{mg} / \mathrm{lit}$ ambient super phosphate and weighed after 7 and 15 days. In each batch six fish were maintained. The difference in their body weights before and after exposure was along with control group taken as change in weight and was expressed in (gm/fish).

Total proteins: Total protein content was estimated by the method of Lowry et al. (1951) eight and was expressed in (gm/fish).

Free amino acids Free amino acid levels were estimated by the method of Moore and Stein (1954)

\section{Results:-}

\section{Total Body Weight}

In the present investigation the fish were exposed to sublethal dose of Single Super Phosphate for different periods of time and total body weights were determined.(table 1 and fig1) The concentration and period of exposure are 400 $\mathrm{mg} / \mathrm{lit}$ and 7 and 15 days respectively decrease in total body weight was observed during 7 and 15 days of exposure. Maximum decrement was observed during 15 days (-40.169) when compare to 7 days (-33.372). All values are significant when compare to conrols.

\section{Total Protein}

The data on variations in total proteins on exposure to single super phosphate are as follows. Fish were exposed to $400 \mathrm{mg} /$ lit of single super phosphatefor 7 and 15 days respectively.(table2 ad fig2) Levels of total protein contains was estimated in liver, muscle, and Gill tissues. On exposure to single super phosphate for different periods of exposure decrease in total protein content was observed in all tissues. The percent decrease was maximum Liver tissue followed by Muscle and Gill. The percent decreased in liver during 7 days (-23.234) and 15 days is (-23.637), in muscle tissue maximum decreased was observed during 7 days (-14.211) when compare to 15 days (-9.801) in Gill tissue the decrement was maximum during 7 days exposure (-7.515) when compare to 15 days (-6.162). All these percent variations are significant at $\mathrm{p}<0.0001$ relative to control values.

\section{Free Amino Acids:-}

Analysis of Free Amino Acids levels in liver, muscle, gill tissue of fish both in control and single super phosphate exposed for 7 and 15 days showed increment over control(table3 and fig3) The increment was highest during 15 days exposure to single super phosphate, when compare to 7 days exposure. All the percent variations are significant at $\mathrm{P}<0.0001$ relative to control values.

\section{Discussion:-}

Body weight in the present investigation showed decrement, it is the indication of utilization or loss of bio chemical constituents such as carbohydrates protein and other metabolites. It indicates the enhancement of catabolism phase during SSP exposure tissue when not active and there was reduction in field intake. This may be the reason for decrease in weight. Application of nitrogen fertilizer in reported to accumulate metabolites which reduce feeding habits of fish and reduction in body weight confirming present study. Decrease in Total Body weight of fish exposed to SSP may be, fish in general are known to be well adapted for mobilizing tissue reverses on stress. This might have decreased boy weight Proteins are the most important Macromolecule in different organs of animals which play a major role in compensatory mechanism of animals during stress conditions. . (Palinivelu.et.al.2005; 
Moorty and Priyamvada, 1982) stated that the protein content of cell may be considered as an important tools for evaluation of physiological standards and it was also stated that depletion in the protein content of the fish indictes the physiological strategy in order to meet the energy demands and to adapt itself to the altered metabolic system which lead to the proteolysis and utilization of the products for increased energy metabolism proteins are involved in major physiological events. The decrease in the protein content may be due to reduced protein synthesis and increased proteolysis and the decreased protein content may be due to break down of proteins in the fabrication of some amount of energy for the organism during stress condition. Free Amino acids are not only the building blocks of proteins but also the important constituent of fish nutrition changes in free amino acids can be correlated with changes in protein synthesis. In the present investigation increase in free amino acid content in different tissues indicates increased proteolysis. This is correlated with reduction in protein content. The increase in free amino acid levels of tissues indicates stopped up proteases activities and fixation of ammonia into keto acids (Srinivas et al. 1986). Thus under single super phosphate effects the protein degradation was predominate and there is increase in Amino acids levels

Table 1 : Total body wt: Changes in the body weight (g/fish) of Channa striatus exposed to urea for 7 and 15 days respectively $\mathrm{C}$ control, Exp = Experimental.

\begin{tabular}{|c|c|c|}
\hline $\begin{array}{l}\text { Exposure } \\
\text { Period (days) }\end{array}$ & Control(c) & Experimental (Exp) \\
\hline 7 & $\begin{array}{ll}30.783 \quad \pm \\
0.160 & \end{array}$ & $\begin{array}{l}20.510 \pm 0.168 \\
(-33.372)\end{array}$ \\
\hline 15 & $\begin{array}{ll}32.876 \quad \pm \\
0.144 & \\
\end{array}$ & $\begin{array}{l}19.670 \pm 0.158 \\
(-40.169)\end{array}$ \\
\hline
\end{tabular}

All the values are Mean \pm SD of six observation Figures in parenthesis are percent increase or decrease over control values are significant.

Table 2: Total Proteins: Changes in total protein content (mg / g wt) wt of tissue is selected tissue of Channa striatus on exposure to $400 \mathrm{mg} / 1$ Super phosphate for $7 \& 15$ days. C control, Exp = Experimental

\begin{tabular}{|c|c|c|c|c|}
\hline \multirow[b]{3}{*}{ Tissues } & \multicolumn{4}{|c|}{ Exposure period (days) } \\
\hline & \multicolumn{2}{|c|}{7} & \multicolumn{2}{|l|}{15} \\
\hline & Control & $\operatorname{Exp}$ & Control & $\operatorname{Exp}$ \\
\hline Liver & $151.44 \pm 0.189$ & $\begin{array}{l}116.255 \pm 0.103 \\
(-23.234)\end{array}$ & $115.53 \pm .968$ & $\begin{array}{l}88.222 \pm .676 \\
(-23.637)\end{array}$ \\
\hline Muscle & $135.04 \pm 2.71$ & $\begin{array}{l}115.85 \pm 0.239 \\
(-14.211)\end{array}$ & $105.81 \pm 5.531$ & $\begin{array}{l}95.44 \pm 1.94 \\
(-9.801)\end{array}$ \\
\hline Gill & $92.685 \pm 0.44$ & $\begin{array}{l}85.720 \pm 0.511 \\
(-7.515)\end{array}$ & $75.35 \pm .783$ & $\begin{array}{l}70.707 \pm .570 \\
(-6.162)\end{array}$ \\
\hline
\end{tabular}

All the values are Mean \pm SD of six observations. Figures in parenthesis are percent increase or decrease over control values is significant.

Table 3: Free Amino Acid: Changes in free amino acid content ( $\mu$ moles of tyrosine equivalents / gram) in selected tissue of Channa striatus on exposure to 400mg/l Superphosphate for 7 and 15 days. C control, Exp = Experimental

\begin{tabular}{|c|c|c|c|c|}
\hline \multirow{3}{*}{ Tissues } & \multicolumn{4}{|c|}{ Exposure period (days) } \\
\hline & \multicolumn{2}{|c|}{7} & \multicolumn{2}{|l|}{15} \\
\hline & Control & $\operatorname{Exp}$ & Control & $\operatorname{Exp}$ \\
\hline Liver & $141.33 \pm 0.736$ & $\begin{array}{l}165.507 \pm 0.280 \\
(17.106)\end{array}$ & $135.70 \pm 2.29$ & $\begin{array}{l}175.73 \pm 0.74 \\
(29.499)\end{array}$ \\
\hline Muscle & $104.82 \pm 1.34$ & $\begin{array}{l}133.89 \pm 1.00 \\
(27.733)\end{array}$ & $108.22 \pm 0.45$ & $\begin{array}{l}156.23 \pm 7.63 \\
(44.363)\end{array}$ \\
\hline Gill & $122.38 \pm 0.134$ & $\begin{array}{l}137.38 \pm 0.914 \\
(12.257)\end{array}$ & $123.38 \pm 0.98$ & $\begin{array}{l}138.74 \pm 0.94 \\
(12.449)\end{array}$ \\
\hline
\end{tabular}


. All the values are Mean \pm SD of six observations. Figures in percent heads are percent increase or decrease over control values are significant

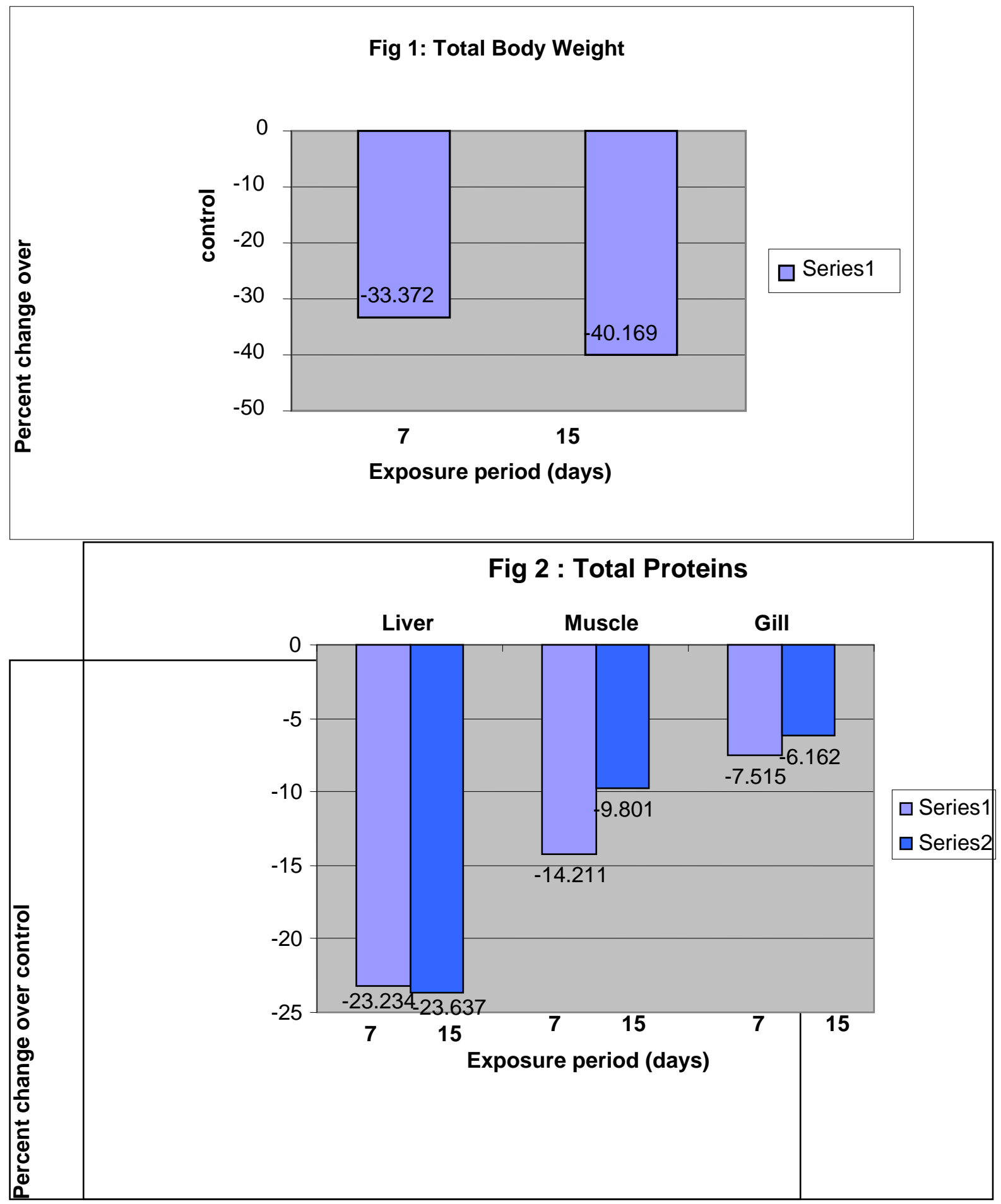




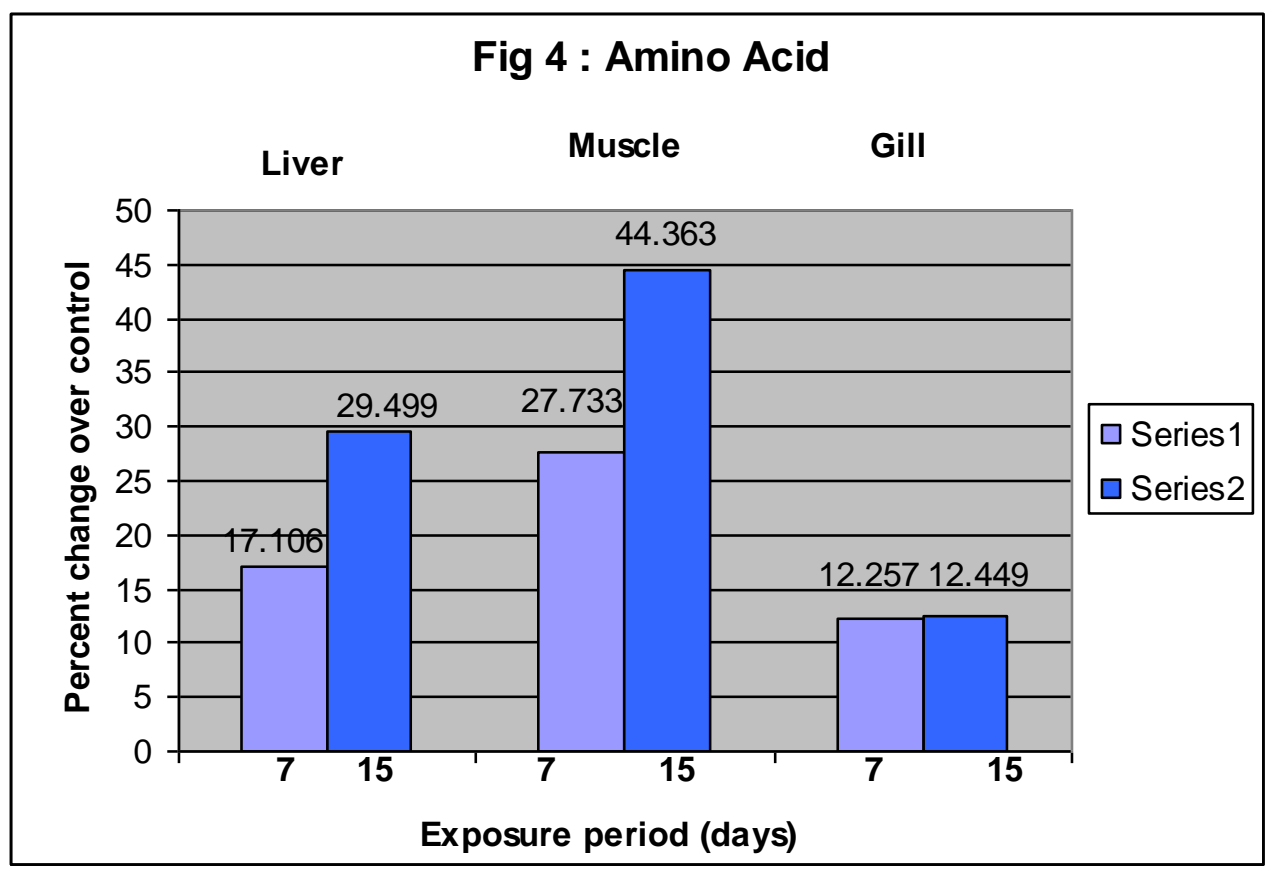

\section{References:-}

1. Bwala,R.L., and Omoregie, E. (2009). Organic enrichment of fish ponds Application of pig dung vs Tilapia a yield Pakistan journal of Nutrition 8(9) 1373-1379.

2. Edwards, C.A. (1973). Environmental pollution by pesticides plumer publishing Co. Ltd London New York p 542

3. Lowry, O.H., Rosenbrough, N.J., Tan and Randall, A.I. (1951). Protein measurement with follin phenol reagent. J. Biol Chem 193; 265-275.

4. Moore, S., and Stain, W.H. (1954). A modified ninhydrin reagent for the photometric determination of amino acids and related compound. J. Biol. Chem (211) 901-913

5. Murthy, A.S., Priyamwada, D.A. (1982). The effect of endosulfan and its isomers on tissue protein glycogen and lipids in the fish channa punctatus J. Pestic. Biochem. Physiol., 17: 280-286.

6. Palanivelu, V., Vijayavel, K., Ezhilarasi balasubramania, M.P., Balasubramanian. (2005). impact of fertilizer (Urea) on oxygen consumption and feeding energetics in the fresh water fish oreochromis mossambicus, environ. Toxicol pharmacology 19(2) 351-352.

7. Saha, G.N., Selvaraj, C., and Mazumder, N.M. (1978). A record of increased fish production in freshwater pond by use of fertilizer alone, Sci, Cult 44(9) : 422-424.

8. Srinivas, M.K., Kasi Reddy., Swamy, K.S., Sri Ramulu. C. (1986). Dichlorovos induced metabolism change in tissues of fresh water murrel. L. Marginalis J. Environ ecol 3-278-279. 